\title{
Physico-chemical composition of feed grade cassava peel meal fermented with different levels of baker's yeast
}

Obasi, I. U., 'Obasi, E. N., Ezeokeke, C. T. and Etuk, E. B.

Department of Animal Science and Technology, Federal University of Technology, Owerri

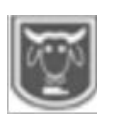

Abstract

${ }^{I}$ Department of Animal Breeding and Physiology, Michael Okpara University of Agriculture, Umudike.

Corresponding author: obasiikechu@gmail.com

This study was conducted to determine the physico-chemical composition of cassava peel meal fermented with varying levels of baker's yeast. Fresh cassava peels (CPM) were milled and divided into four groups and each group was randomly assigned to Angel baker's yeast at $0.0 \%, 0.2 \%, 0.4 \%$ and $0.6 \%$, respectively. Each group $(0.00 \%, 0.20 \%, 0.40 \%$ and $0.60 \%)$ was further divided into four subgroups and each subgroup again randomly assigned to 0 hours, 24 hours, 48 hours and 72 hours fermentation duration, respectively in a $4 \times 4$ factorial arrangement of a completely randomized design (CRD). The treated CPM samples were thereafter sundried, analysed for proximate and gross energy composition as well as Bulk density (BD) and water holding capacity (WHC). Results from this study indicated a significant $(p<0.05)$ increase in crude protein $(C P)$ content of $C P M$ with increasing levels of yeast with $0.60 \%$ yeast level recording significantly higher $(p<0.05)$ value $(13.50 \%)$ than $0.00 \%(6.59 \%)$. The crude fibre content of cassava peel meal (CPM) treated with different levels of baker's yeast showed no significant $(p>0.05)$ difference. Ether Extract (EE) decreased with increasing levels of baker's yeast from (0.20\%). No discernible trend was recorded in the ash content of CPM at different levels of baker's yeast, though the control $(0.00 \%)$ recorded significantly higher $(p<0.05)$ ash value $(11.38 \%)$ than $0.20 \%$ and $0.60 \%$. Baker's yeast levels effect showed a consistent decline in NFE values with increasing levels of baker's yeast, values for $0.00 \%$ and $0.20 \%$ were significantly higher $(p<0.05)$ than those for $0.40 \%$ and $0.60 \%$. Bulk density increased with level of baker's yeast and duration of fermentation achieving a peak value $\left(0.38 \mathrm{~g} / \mathrm{cm}^{3}\right)$ at $0.60 \%$. Water holding capacity conversely reduced with increasing duration and fermentation with the highest value $(1.65 \mathrm{~g}$ water/ $g$ feed).The baker's yeast level effect showed increased gross energy with increasing levels of baker's yeast for fermented cassava peel. The use of baker's yeast in cassava peel fermentation proved to be a means of nutrient enrichment for cassava peels.

Keywords: Cassava peels; fermentation; baker's yeast; duration; levels

\section{Introduction}

The Nigerian government has in the last couple of years actively pursued policies and programmes that is directed towards encouraging cassava production (Elijah, 2015). This has resulted in an all year round availability of cassava, making Nigeria the world's foremost cassava producers and accounting for about $20 \%$ global cassava production. More than $95 \%$ of utilizable cassava products require peeling of the cassava tuber and this process generates up to 14 metric tonnes of peels as waste annually (FAOSTAT, 2015). Furthermore, cassava starch and chips production units that process tonnes of tubers per day are increasingly springing up as well as the already well established local processing of cassava into food products like garri, fufu etc. The first step in processing these tubers is the removal of the bark which is the outermost layer and the peel which is the 
thick cover of the tubers; these merely end up as waste or sometimes as supplementary feed for ruminants (Adeyemi and Sani, 2013). Enormous quantity of cassava peels are therefore, produced from these cassava processing activities. This may cause environmental problems when left in surroundings of processing plants or carelessly disposed off. Cassava processing produces large amount of waste and is considered to contribute significantly to environmental pollution (FAO, 2001). In Nigeria, for example, cassava waste are usually left to rot away or burnt to create space for accumulation of yet more waste heaps. The heaps emit carbon dioxide and produce strong offensive smell (Adebayo, 2008; Aro et al, 2010). A typical cassava starch production unit processing 100tons of tubers per day could produce about 47 tons of fresh by-products. (Aro et al, 2010).Pandy et al. (2000) however, reported that the use of cassava by-products as feed or as an alternative substrate for biotechnology is a positive way to alleviate these environmental issues.

Cassava peels can represent 5 to $15 \%$ of the root and like most agricultural wastes are made up of polysaccharides which are wide spread in nature (Gardnea, 1974; Nwokoro et al., 2005; Aro et al., 2010). The peels are obtained after the tubers have been watercleansed and peeled mechanically (Aro et $a l ., 2010)$ and may contain high amount of cyanogenic glucoside and higher protein content than other tuber parts (Tewe, 2004). Generally, cassava peels lave low protein content $(<6 \% \mathrm{DM})$ and variable fibre content (10-30\% DM) (Heuze et al., 2014). The fallout of these constraints on nonruminant animal feeding includes low digestibility, poor feed intake and reduced animal performance (Adegbola and Oduoza, 2002). Egbunike et al. (2009) reported decreased performance with up to $5 \%$ inclusion of cassava peel meal in broilers diets and Osei et al. (1990) suggested that cassava peel meal should be used carefully in diets for laying birds with inclusion rate of $5 \%$. The poor utilization of cassava peels has therefore, prompted evaluation of different methods with the aim of improving nutritional value and perhaps dietary inclusion levels of cassava peels for non ruminant animals particularly poultry. In order to reduce the cyanogenic glucoside, sun-drying, ensiling and soaking have yielded satisfactory results (Adegbola et al., 1985; Tewe, 1992; Salami et al., 2003). Enzymes have also been used to improve the nutritional value of cassava peels. Solid state fermentation of a mixture of cassava peels and waste water from fermented cassava pulp with Saccharomyces cerevisae and Lactobacillus spp has been reported to result in a product with higher protein content, lower cyanogenic glucoside and low phytate content (Oboh, 2006; Ubulua, 2007).

Fermentation is one of the oldest technologies that have been used in food processing for over 600 years (Mortarjem, 2002). Fermentation enhances the nutrient content of food, the biosynthesis of vitamins, essential amino acids, protein quality and fibre digestibility. Fermentation of cassava peel with yeast have also been reported to increase protein content from $2.4 \%$ in non-fermented to $14 \%$ in fermented peels (Antai and Mbongo, 1994). Oboh and Akindahunsi (2003) reported increased digestibility of cassava peels fermented with yeast.

Apart from the determined nutritional content, physical characteristics of feedstuffs contribute to its nutritional quality. Physical characteristics of any feed-stuff or feed includes all the quantitative and qualitative expressions of the material features of such feedstuff that have visible or tangible attributes and can 


\section{Obasi, Obasi, Ezeokeke and Etuk}

be used in describing its natural structural physical characteristics (Portella et al., 1988; Sundu et al., 2005). The four most important physical characteristics that greatly influence the nutritional value,intake and performance of poultry diets are Water Holding capacity (WHC), Bulk Density (BD), Particle Size (PS) and Specific Gravity (SG). These attributes play important roles in controlling feeding (Makinde and Sonaiya, 2007; Okoli et al., 2012). The BD of feed materials used in the Nigerian feed industries ranges from 0.02$0.41 \mathrm{~g} / \mathrm{cm}^{2}$ while the WHC of energy and novel feedstuffs ranges from $0.35-0.89(\mathrm{~g}$ water/g feed) (Omede et al., 2011). Information on the physical characteristics and chemical composition of feedstuffs could therefore, serve as an indicator of the value of such feedstuff in animal feeding.

This study therefore, aimed at determining the physical attributes and chemical composition of cassava peel meal fermented with different levels of baker's yeast.

\section{Materials and methods \\ Fermentation of cassava peels with baker's yeast}

Fresh cassava peels used for this study were collected from cassava-processing centres around Eziobodo in Owerri West L.G.A. The fresh peels were milled through an Epic Agro® grater with $2 \mathrm{~mm}$ sieve. The freshly milled cassava peels (CPM) were divided into four groups of $3 \mathrm{~kg}$ each and each group was randomly assigned one of the quantity of Angels ${ }^{\circledR}$ baker's yeast; $0 \mathrm{~g}$ baker's yeast $/ \mathrm{kg}$ CPM, 2.0g baker's yeast $/ \mathrm{kg}$ CPM, $4.0 \mathrm{~g}$ baker's yeast $/ \mathrm{kg}$ CPM and $6.0 \mathrm{~g}$ baker's yeast $/ \mathrm{kg}$ CPM which translated into 0, 0.20, 0.40 and $0.60 \%$ of baker's yeast per treatment group, respectively. The required quantity of Angels ${ }^{\circledR}$ yeast $/ \mathrm{kg} \mathrm{CPM}$ for each treatment group was dissolved in $40 \mathrm{~cm}^{3}$ of Eva ${ }^{\circledR}$ bottled water to form a consistent yeast solution and thereafter thoroughly mixed with the cassava peel meal in a plastic container. Each treatment group was then fermented for $0,24,48$ and 72 hours in three replicates of $1 \mathrm{~kg}$ each in a $4 \times 4$ factorial arrangement of a completely randomized design. The samples were left to ferment in an aerobic condition for the required duration except the group on 0 hour fermentation. After fermentation, the samples were sundried in replicates until they became crispy (about 3 days), pulverized to a fine powder and samples for analysis taken on replicate basis.

Proximate and gross energy determination

Proximate composition was determined using AOAC (2010), while gross energy was determined using the bomb calorimeter method as outlined by AOAC (1995).

Determination of physical characteristics Bulk density

The method described by Makinde and Sonaiya (2007) was adopted with slight modification. To obtain $\mathrm{BD}$ of the experimental material, a pyrex glass funnel of known volume was weighed and test sample was poured into it and then leveled off. The funnel and its content were weighed again and initial weight of funnel was subtracted from the final weight to obtain the weight of the test material. The weight of the test material was then divided by the volume of the funnel.

\section{Water holding capacity}

The filtration method described by Makinde and Sonaiya (2007) was again adopted with slight modification. The initial weight of the funnel and its content was subtracted from the weight of wet set-up to obtain the weight of water absorbed by the test sample.

\section{Statistical analysis}

Data collected were subjected to analysis of variance (ANOVA) as outlined by Snedecor and Cochran (1978). Duncan New multiple Range Test (DNMRT) as outlined by Obi 
(1990) was used to separate the means where significant treatment effect existed, using the $\mathrm{R}$ - Core Application (R-core Team, 2012).

\section{Results and discussion \\ Chemical composition of cassava peel mealfermented with baker's yeast}

The main effects of fermentation duration and level of baker's yeast on proximate and gross energy composition of cassava peels are presented in Table 1. Crude protein (CP) content of the cassava peel meal fermented with baker's yeast ranged from 5.83\% obtained for treatment on $14.48 \%$ for $0.60 \% \times 72 \mathrm{hrs}$.Crude fibre content of CPM ranged from $15.12 \%$ for $0.60 \%$ x 48 hours to $20.77 \%$ for $0 \% \mathrm{x} 0 \mathrm{hr}$. Crude fibre value decreased with duration of fermentation up to 48 hours for CPM samples with $0.20 \%$, $0.40 \%$ and $0.60 \%$ baker's yeast. The crude fibre content of cassava peel meal observed in this study was within the range of $10.3-$ $31.8 \%$ reported by INRA et al. (2012). The ether extract values obtained in this study ranged from $0.56-1.09 \%$ and was lower than the $1.3 \%$ reported by INRA et al. (2012). The ash content of fermented CPM in all the treatment groups ranged from 8.81 to $12.67 \%$ with treatments $0.20 \% \times 24 \mathrm{hrs}$ and $0 \% \mathrm{x} 0 \mathrm{hrs}$ recording the highest and lowest values, respectively.

On the other hand, the NFE content of fermented CPM showed an increase with level of baker's yeast up to $48 \mathrm{hrs}$ fermentation duration except at 0.40 and $0.60 \%$ baker's yeast levels. The highest NFE value was observed in treatment $0 \%$ x 48 hrs $(65.04 \%)$ while the lowest value was $54.89 \%$ at $0.40 \% x 0 \mathrm{hr}$. Gross energy of fermented CPM ranged from $3208.44 \mathrm{Kcal} / \mathrm{kg}$ to $3526.69 \mathrm{Kcal} / \mathrm{kg}$. These values were much lower than the range $3917.07 \mathrm{kcal} / \mathrm{kg}$ to $4227.57 \mathrm{kcal} / \mathrm{kg}$ reported for fresh cassava peels by INRA $e t$ al. (2012). Ukachukwu (2005) also obtained a slightly higher gross energy $(3.64 \mathrm{Kcal} / \mathrm{g})$ for composite cassava product. However, gross energy value of fermented cassava peel was higher at $0.60 \%$ level of baker's yeast in all the fermentation duration.

Effects of duration of fermentation on the proximate and gross energy composition of CPM are presented in Table 2. Crude protein $(\mathrm{CP})$ value decreased up to 48 hours fermentation duration and the control (Ohr) produced the highest value. This result was at variance with the report of Boonnop (2014). Crude fibre showed a consistent reduction up to 48hours fermentation duration but increased at 72 hours fermentation duration. Fermentation duration therefore, did not show any consistent effect on the ether extract content though the highest value was obtained at 72hours fermentation duration. Oboh and Elusiyan (2007) reported an increased fat and reduced carbohydrate content of cassava flour treated with $S$. cerevisae. Increase in fat might have been as a result of the secretion of microbial oil during fermentation (Akindumila and Glatz, 1998; Oboh and Akinahunsi, 2003).

Nitrogen Free Extract (NFE) value increased with duration of fermentation up to $48 \mathrm{hrs}$ with the control ( $0 \mathrm{hr}$ ) recording a significantly lower $(\mathrm{p}<0.05) \quad$ NFE value $(56.78 \%)$ than the other groups. The report of Oboh and Akindahunsi (2003) that observed 64.6, 67.3 and $60.5 \%$ NFE in unfermented, naturally fermented and inoculated fermented cassava peels, respectively seemed to corroborate the observed pattern in this study. Ash content of CPM indicated a consistent decrease up to $48 \mathrm{hrs}$ fermentation duration with the control (0hr) recording a significantly higher $(p<0.05)$ value $(11.50 \%)$ than other groups. Gross energy increased with increasing fermentation duration resulting in the control $(0 \mathrm{hr})$ and $72 \mathrm{hrs}$ recording the lowest and highest values, respectively. 
Obasi, Obasi, Ezeokeke and Etuk

Table 1: Interaction of baker's yeast and duration of fermentation on proximate composition and gross energy of cassava peel meal

\begin{tabular}{|c|c|c|c|c|c|c|c|c|}
\hline \multirow[b]{2}{*}{ 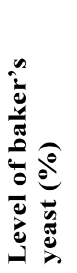 } & \multirow[b]{2}{*}{ مَّة } & \multicolumn{7}{|c|}{ Proximate Composition (\%) and Gross Energy values (kcal/kg) } \\
\hline & & 吾 & 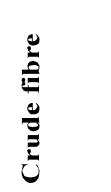 & 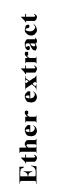 & $\overline{4}$ & 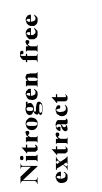 & 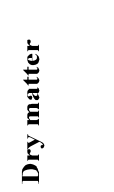 & 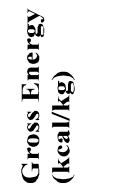 \\
\hline \multirow{5}{*}{0.00} & 0 & $7.16^{\mathrm{ij}}$ & $20.77^{\mathrm{ab}}$ & $0.94^{\mathrm{a}}$ & $12.67^{\mathrm{a}}$ & $58.43^{\text {cd }}$ & $82.46^{\mathrm{f}}$ & $3208.44^{\mathrm{f}}$ \\
\hline & 24 & $7.00^{\mathrm{ij}}$ & $20.56^{\mathrm{bc}}$ & $1.05^{\mathrm{ab}}$ & $11.62^{\mathrm{ab}}$ & $59.74^{\mathrm{bc}}$ & $83.26^{\mathrm{ef}}$ & $3254.02^{\text {ef }}$ \\
\hline & 48 & $5.84^{\mathrm{j}}$ & $17.65^{\mathrm{fgh}}$ & $0.71^{\mathrm{ab}}$ & $10.60^{\text {bcde }}$ & $65.04^{\mathrm{a}}$ & $84.73^{\text {bcdef }}$ & $3403.58^{\mathrm{abc}}$ \\
\hline & 72 & $6.36^{\mathrm{j}}$ & $16.86^{\mathrm{gh}}$ & $1.09^{\mathrm{ab}}$ & $10.64^{\text {bcde }}$ & $64.76^{\mathrm{a}}$ & $89.50^{\mathrm{a}}$ & $3288.78^{\text {def }}$ \\
\hline & 0 & $10.46^{\mathrm{fg}}$ & $18.17^{\mathrm{efg}}$ & $0.88^{\mathrm{ab}}$ & $10.96^{\text {abcd }}$ & $59.49^{\mathrm{bc}}$ & $83.23^{\mathrm{ef}}$ & $3249.70^{\text {ef }}$ \\
\hline \multirow{3}{*}{0.20} & 24 & $9.63^{\text {fgh }}$ & $19.35^{\text {bcde }}$ & $0.86^{\mathrm{ab}}$ & $8.81^{\mathrm{f}}$ & $61.41^{\mathrm{b}}$ & $83.40^{\text {def }}$ & $3324.17^{\text {cdef }}$ \\
\hline & 48 & $8.24^{\mathrm{hi}}$ & $16.17^{\mathrm{hi}}$ & $0.99^{\mathrm{a}}$ & $9.58^{\text {cdef }}$ & $64.81^{\mathrm{a}}$ & $84.13^{\text {cdef }}$ & $3364.74^{\text {bcde }}$ \\
\hline & 72 & $9.17^{\text {gh }}$ & $20.43^{\mathrm{bc}}$ & $1.07^{\mathrm{a}}$ & $10.82^{\mathrm{bcd}}$ & $58.45^{\mathrm{cd}}$ & $87.57^{\mathrm{ab}}$ & $3526.69^{\mathrm{a}}$ \\
\hline \multirow{5}{*}{0.40} & 0 & $11.06^{\mathrm{def}}$ & $22.21^{\mathrm{a}}$ & $0.81^{\mathrm{ab}}$ & $11.00^{\mathrm{abcd}}$ & $54.89^{\mathrm{e}}$ & $85.80^{\text {bcde }}$ & $3254.91^{\mathrm{ef}}$ \\
\hline & 24 & $12.30^{\mathrm{bcd}}$ & $18.82^{\text {def }}$ & $1.00^{\mathrm{a}}$ & $10.23^{\text {bcdef }}$ & $57.01^{\text {cde }}$ & $84.76^{\text {bcdef }}$ & $3354.00^{\text {bcde }}$ \\
\hline & 48 & $11.96^{\text {cde }}$ & $17.72^{\mathrm{fg}}$ & $0.77^{\mathrm{ab}}$ & $11.07^{\mathrm{abc}}$ & $58.39^{\mathrm{cd}}$ & $85.13^{\text {bcdef }}$ & $3364.74^{\text {bcde }}$ \\
\hline & 72 & $11.58^{\mathrm{efg}}$ & $19.37^{\text {bcde }}$ & $1.00^{\mathrm{a}}$ & $9.32^{\mathrm{def}}$ & $59.69^{\mathrm{bc}}$ & $86.60^{\mathrm{abc}}$ & $3364.74^{\text {bcde }}$ \\
\hline & 0 & $13.66^{\mathrm{ab}}$ & $20.09^{\mathrm{bcd}}$ & $0.56^{\mathrm{b}}$ & $11.37^{\mathrm{ab}}$ & $54.34^{\mathrm{e}}$ & $85.63^{\text {bcdef }}$ & $3478.14^{\mathrm{ab}}$ \\
\hline \multirow{3}{*}{0.60} & 24 & $12.82^{\mathrm{bc}}$ & $20.06^{\mathrm{bcd}}$ & $0.84^{\mathrm{ab}}$ & $10.25^{\text {bcdef }}$ & $56.37^{\mathrm{de}}$ & $86.46^{\mathrm{bc}}$ & $3453.87^{\mathrm{abc}}$ \\
\hline & 48 & $13.04^{\mathrm{abc}}$ & $15.12^{\mathrm{i}}$ & $0.84^{\text {aa }}$ & $9.05^{\mathrm{ef}}$ & $61.93^{b}$ & $85.10^{\text {bcdef }}$ & $3431.90^{\mathrm{abc}}$ \\
\hline & 72 & $14.48^{\mathrm{a}}$ & $19.13^{\text {cdef }}$ & $0.70^{\mathrm{ab}}$ & $10.85^{\text {bde }}$ & $55.12^{\mathrm{e}}$ & $86.23^{\text {bcd }}$ & $3464.52^{\mathrm{ab}}$ \\
\hline SEM & & 0.40 & 0.28 & 0.03 & 0.18 & 0.53 & 0.33 & 16.47 \\
\hline
\end{tabular}

abcdefghij Means within a column with different superscript are significantly different $(\mathrm{p}<0.05)$

Table 2: Effect of fermentation durations on the pro ximate composition and gross energy of cassava peel meal

\begin{tabular}{llllll}
\hline \multirow{2}{*}{ Parameters } & \multicolumn{4}{c}{ Duration of fermentation (hours) } & \multirow{2}{*}{ SEM } \\
\cline { 2 - 5 } & $\mathbf{0}$ & $\mathbf{2 4}$ & $\mathbf{4 8}$ & $\mathbf{7 2}$ & \\
\hline Dry Matter (\%) & $84.28^{\mathrm{b}}$ & $84.47^{\mathrm{b}}$ & $84.77^{\mathrm{b}}$ & $87.47^{\mathrm{a}}$ & 0.33 \\
Crude protein (\%) & $10.59^{\mathrm{a}}$ & $10.44^{\mathrm{ab}}$ & $9.78^{\mathrm{b}}$ & $10.15^{\mathrm{ab}}$ & 0.40 \\
Crude fibre (\%) & $20.31^{\mathrm{a}}$ & $19.70^{\mathrm{a}}$ & $16.66^{\mathrm{c}}$ & $18.94^{\mathrm{b}}$ & 0.28 \\
Ether extract (\%) & $0.79^{\mathrm{a}}$ & $0.93^{\mathrm{b}}$ & $0.83^{\mathrm{a}}$ & $0.94^{\mathrm{b}}$ & 0.03 \\
Ash (\%) & $11.50^{\mathrm{a}}$ & $10.25^{\mathrm{b}}$ & $10.07^{\mathrm{b}}$ & $10.34^{\mathrm{b}}$ & 0.18 \\
Nitrogen free extract (\%) & $56.78^{\mathrm{c}}$ & $58.63^{\mathrm{b}}$ & $62.54^{\mathrm{a}}$ & $59.50^{\mathrm{b}}$ & 0.53 \\
Gross Energy (Kcal/kg) & $3288.71^{\mathrm{c}}$ & $3366.33^{\mathrm{b}}$ & $3337.10^{\mathrm{bc}}$ & $3457.11^{\mathrm{a}}$ & 16.49 \\
\hline
\end{tabular}

$\overline{\text { abc }}$ Means within a row with different superscripts are significantly different $(\mathrm{p}<0.05)$

The inclusion of baker's yeast (Table 3) indicated an increase in CP content of CPM with increasing levels of yeast. Treatment with $0.60 \%$ yeast recorded significantly higher $(\mathrm{p}<0.05)$ value $(13.50 \%)$ than $6.59 \%$ obtained for the control $(0.00 \%)$. Oboh and Akindahunsi (2003) similarly, reported $11.1 \%$ protein for naturally fermented and 
$14.0 \%$ for inoculated fermented compared to $8.2 \%$ protein for unfermented cassava peel meal. Ether extract value decreased with increasing levels of baker's yeast from $0.20 \%$. Baker's yeast levels effect did not follow any discernible pattern though the control $(0.00 \%)$ recorded significantly higher $(\mathrm{p}<0.05)$ ash value $(11.38 \%)$ than $0.20 \%$ and $0.60 \%$.Conversely, inclusion of baker's yeast produced a consistent decline in NFE values with increasing levels. NFE values for $0.00 \%$ and $0.20 \%$ were significantly higher $(\mathrm{p}<0.05)$ than those for $0.40 \%$ and $0.60 \%$. The decrease might be attributed to the fungi/bacterial complex which hydrolyzed starch into glucose for use by the microorganisms to synthesize fungi/bacteria biomass rich in protein (Oboh et al., 2002; Osman, 2011). Similarly, gross energy increased with increasing levels of baker's yeast.

Table 3: Effect of Baker's yeast inclusion on the proximate compositio $\mathbf{n}$ and gross energy of cassava peel meal

\begin{tabular}{llllll}
\hline \multirow{2}{*}{ Parameters } & \multicolumn{4}{c}{ Levels of baker's yeast (\%) } & \multirow{2}{*}{ SEM } \\
\cline { 2 - 5 } & $\mathbf{0 . 0 0}$ & $\mathbf{0 . 2 0}$ & $\mathbf{0 . 4 0}$ & $\mathbf{0 . 6 0}$ & \\
\hline Dry Matter (\%) & $84.99^{\mathrm{ab}}$ & $84.58^{\mathrm{b}}$ & $85.57^{\mathrm{a}}$ & $85.85^{\mathrm{a}}$ & 0.33 \\
Crude protein (\%) & $6.59^{\mathrm{d}}$ & $9.37^{\mathrm{c}}$ & $11.48^{\mathrm{b}}$ & $13.50^{\mathrm{b}}$ & 0.40 \\
Crude fibre (\%) & $18.96^{\mathrm{ab}}$ & $18.53^{\mathrm{a}}$ & $19.53^{\mathrm{b}}$ & $18.60^{\mathrm{a}}$ & 0.28 \\
Ether extract (\%) & $0.93^{\mathrm{a}}$ & $0.95^{\mathrm{a}}$ & $0.89^{\mathrm{ab}}$ & $0.72^{\mathrm{b}}$ & 0.03 \\
Ash (\%) & $11.38^{\mathrm{a}}$ & $10.04^{\mathrm{b}}$ & $10.43^{\mathrm{ab}}$ & $10.31^{\mathrm{b}}$ & 0.18 \\
Nitrogen free extract (\%) & $52.88^{\mathrm{a}}$ & $51.95^{\mathrm{a}}$ & $49.18^{\mathrm{b}}$ & $48.94^{\mathrm{b}}$ & 0.53 \\
Gross Energy (kcal/kg) & $3297.80^{\mathrm{b}}$ & $3346.52^{\mathrm{ab}}$ & $3391.25^{\mathrm{b}}$ & $3413.68^{\mathrm{a}}$ & 16.48 \\
\hline
\end{tabular}

$\overline{\text { abcd }}$ Means within a row with difference superscripts are significantly different $(\mathrm{p}<0.05)$

Physical characteristics of cassava peel meal fermented with baker' yeast

The main effect of baker's east and duration of fermentation on the physical characteristics of cassava peels meal is presented in Table 4. The Bulk Density (BD) of CPM obtained in this study showed a consistent increase with increasing fermentation duration and somewhat with level of baker's yeast. The highest $\mathrm{BD}$ value $\left(0.39 \mathrm{~g} / \mathrm{c} \mathrm{m}^{3}\right)$ were recorded in $0.60 \% \times 48$ hours and $0.60 \% \times 72$ hours, while the lowest BD value $\left(0.31 \mathrm{~g} / \mathrm{cm}^{3}\right)$ was observed in $0.00 \% \mathrm{x} 0$ hour These values fall within the range $(0.02-0.73 \mathrm{~g} / \mathrm{cm} 3)$ reported for feed materials used in the Nigerian feed industry (Omede et al., 2011). The Water Holding Capacity (WHC) of CPM ranged from $1.25 \mathrm{~g}$ water $/ \mathrm{g}$ feed for $0.40 \% \times 72$ hours to $1.79 \mathrm{~g}$ water $/ \mathrm{g}$ feed for $0.00 \% x 0$ hours. This result reflects a decreasing WHC with increasing duration of fermentation up to $0.20 \%$.

Effect of baker's yeast inclusion on the BD of CPM showed an increase with increasing level baker's yeast (Table 5) while fermentation duration effect (Table 6) showed an increase of BD with increasing duration of fermentation. Ogbo and Odo (2011) suggested that the increased BD in cassava peel meal might have resulted from a high concentration of smaller and powdery particles as well as a more water soluble starch component. Also, feedstuff with concentrated source of fibre has low bulk density (Sundu et al., 2005; De Leeun et al., 2008). 
Obasi, Obasi, Ezeokeke and Etuk

Table 4: Interaction of baker's yeast and duration of fermentation on physical properties of cassava peel meal (CPM)

\begin{tabular}{|c|c|c|c|}
\hline \multirow[b]{2}{*}{$\begin{array}{c}\text { Level of } \\
\text { baker's } \\
\text { yeast }(\%)\end{array}$} & \multirow[b]{2}{*}{$\begin{array}{c}\text { Duration of } \\
\text { fermentation } \\
\text { (hours) }\end{array}$} & \multicolumn{2}{|c|}{ Physical properties of fermented CPM } \\
\hline & & Bulk density $\left(\mathrm{g} / \mathrm{cm}^{3}\right)$ & $\begin{array}{l}\text { Water holding } \\
\text { capacity(g water/g } \\
\text { feed) }\end{array}$ \\
\hline \multirow{5}{*}{0.00} & 0 & $0.31^{\mathrm{h}}$ & $1.79^{\mathrm{a}}$ \\
\hline & 24 & $0.33^{\mathrm{gh}}$ & $1.7^{\mathrm{ab}}$ \\
\hline & 48 & $0.38^{\operatorname{defg}}$ & $1.60^{\mathrm{abcd}}$ \\
\hline & 72 & $0.35^{\operatorname{defg}}$ & $1.45^{\text {bcdef }}$ \\
\hline & 0 & $0.34^{\mathrm{efgh}}$ & $1.62^{\mathrm{abc}}$ \\
\hline \multirow{3}{*}{0.20} & 24 & $0.33^{\text {fgh }}$ & $1.52^{\text {abcdef }}$ \\
\hline & 48 & $0.37^{\mathrm{abcd}}$ & $1.38^{\text {cdef }}$ \\
\hline & 72 & $0.38^{\mathrm{ab}}$ & $1.36^{\mathrm{cdef}}$ \\
\hline \multirow{5}{*}{0.40} & 0 & $0.35^{\text {cdefg }}$ & $1.36^{\text {cdef }}$ \\
\hline & 24 & $0.36^{\text {bcdefg }}$ & $1.57^{\text {abcde }}$ \\
\hline & 48 & $0.35^{\text {bcdefg }}$ & $1.31^{\mathrm{def}}$ \\
\hline & 72 & $0.36^{\text {abcdef }}$ & $1.25^{\mathrm{f}}$ \\
\hline & 0 & $0.37^{\text {abcde }}$ & $1.54^{\mathrm{abcdef}}$ \\
\hline \multirow{3}{*}{0.60} & 24 & $0.38^{\mathrm{abc}}$ & $1.26^{\mathrm{ef}}$ \\
\hline & 48 & $0.39^{\mathrm{a}}$ & $1.43^{\text {cdef }}$ \\
\hline & 72 & $0.39^{\mathrm{ab}}$ & $1.59^{\mathrm{abcd}}$ \\
\hline SEM & & 0.02 & 0.04 \\
\hline
\end{tabular}

abcdefg Means within a column with different superscript are significantly different $(\mathrm{p}<0.05)$

Table 5: Effects of baker's yeast inclusion on the physical properties of cassava peel meal

\begin{tabular}{|c|c|c|c|c|c|}
\hline \multirow{2}{*}{ Parameters } & \multicolumn{4}{|c|}{ Level of baker's yeast (\%) } & \multirow{2}{*}{ SEM } \\
\hline & 0.00 & 0.20 & 0.40 & 0.60 & \\
\hline Bulk density $\left(\mathrm{g} / \mathrm{cm}^{3}\right)$ & $0.34^{\mathrm{b}}$ & $0.35^{\mathrm{ab}}$ & $0.38^{\mathrm{a}}$ & $0.37^{\mathrm{ab}}$ & 0.10 \\
\hline $\begin{array}{l}\text { Water holding capacity (g } \\
\text { water/g feed) }\end{array}$ & 1.58 & 1.53 & 1.43 & 1.41 & $0.04^{\mathrm{ns}}$ \\
\hline
\end{tabular}

Effects of baker's yeast levels on the WHC showed similar $(\mathrm{p}>0.05)$ values at all levels (Table 5). The WHC however, showed a decreasing trend with increase in the level of baker's yeast. A Similar trend was recorded with the fermentation duration which decreased from 1.65 to $1.38 \mathrm{~g}$ water/g feed) for 0.00 and $0.60 \%$ levels of baker's yeast, respectively (Table 6). The WHC values obtained for 0.00 and $0.60 \%$ baker's yeast levels where significantly $(p<0.05)$ different from other groups. The values obtained in this study were nevertheless, much higher than the 0.35 to $0.89 \mathrm{~g}$ water/ $\mathrm{g}$ feed reported by Omede et al., (2011) for energy sources and novel feedstuff. It is therefore, possible that the high fibre content of the CPM might have resulted in the high WHC due to the fact that feedstuff with concentrated sources of fibre or non 
Physico-chemical composition of feed grade cassava peel meal fermented with different levels of baker's yeast

starch polysaccharides (NSP) have been shown to hold a lot of water and have high
WHC but low bulk density (Smith and Annison, 1996; Sundu et al., 2005; Deleeun etal., 2008)

Table 6: Effects of fermentation duration on the physical properties of cassava peel meal

\begin{tabular}{llllll}
\hline & \multicolumn{5}{c}{ Fermentation duration (hours) } \\
\cline { 2 - 6 } Parameters & $\mathbf{0}$ & $\mathbf{2 4}$ & $\mathbf{4 8}$ & $\mathbf{7 2}$ & SEM \\
\hline Bulk density $\left(\mathrm{g} / \mathrm{cm}^{3}\right)$ & $0.35^{\mathrm{b}}$ & $0.36^{\mathrm{ab}}$ & $0.36^{\mathrm{ab}}$ & $0.38^{\mathrm{a}}$ & 0.10 \\
Water holding capacity (g water/g & $1.65^{\mathrm{a}}$ & $1.48^{\mathrm{ab}}$ & $1.46^{\mathrm{b}}$ & $1.38^{\mathrm{b}}$ & 0.04 \\
feed) & & & & \\
\hline
\end{tabular}

${ }^{\mathrm{ab}}$ Means within a row with different superscript are significantly different $(\mathrm{p}<0.05) .{ }^{\mathrm{ns}}=$ not significant.

\section{Conclusion and recommendation}

The fermentation of cassava peel meal (CPM) with baker's yeast improved the crude protein content, particularly at $0.60 \%$ level of baker's yeast and 72 hours duration of fermentation. Similarly, fermentation improved the gross energy content of CPM while there was an increase in bulk density (BD) and reduction in water holding capacity (WHC) with increasing level of baker's yeast and duration of fermentation.

The use of baker's yeast at $0.60 \%$ and 72 hours fermentation duration for nutrient enrichment of cassava peels is recommended. Pure yeast inoculants should be used in future studies on nutrient enrichment of cassava peels meal to ascertain the benefits or otherwise of the use of yeast.

\section{Acknowledgement}

The authors acknowledge the contribution of the Head of Department of Animal Science and Technology, Federal University of Technology Owerri for providing research facilities for this study and JaaGee Nigeria Limited for providing confirmatory laboratory services.

\section{References}

Adebayo, A. O. 2008. Using cassava waste to raise goats. Project 20084345.World Bank Development
Marketplace.

Adeyemi, I. A. and Sani, A. 2013. Haematological parameters and serum biochemical indices of broiler chicken fed Aspergillius niger hydrolysed cassava peel meal based diet. International Journal Agricultural Policy Research, 1(6):166-171

Adegbola, T. A. and Oduoza, P. C. 2002. Nutrient intake digestibility and performance of rabbit fed varying levels of fermented and unfermented cassava peel meal. Journal of Animal Production Research. 12(1): 41-47.

Adegbola, A. A. and Asaolu, O. 1985. Preparation of cassava peels for use in small ruminant production in western Nigeria. ILRI, Towards optimal feeding of agricultural byproduct to livestock in Africa.

Akindadumila, F. and Glatz, B. A. 1998. Growth and oil production apiotrichum curvatunm in tomatoe juice. Journal of food protection, V.61 p. 1515-1517.

Antai, S. P. and Mbongo, P. M. 1994. Utilization of cassava peels as substrate for crude protein formation. Plant Foods for Human Nutrition 46(4): 345 - 351

AOAC 2010. Official methods of analysis, 
$18^{\text {th }}$ edition, revision 3 , Association of Official analytical chemists, Washington DC.

AOAC 1995. official methods 978.10 fiber (crude) in an feed-fritted glass crucible method. $16^{\text {th }}$ edition vol. 1 chapter 4 p. 19.

Aro. S. O., Aletor V. A., Tewe O. O. and Agbede J. O. 2010. Nutritional potentials of cassava tuber waste: A case study of a cassava processing factory in south western Nigeria. Livestock Research for Rural $\mathrm{D}$ e v e 1 o $\mathrm{p} \mathrm{m} \mathrm{e} \mathrm{n} \mathrm{t} .22$ (11)http://www.irrd.org/irrd22/11/ aro22213.htm. accessed February 3, 2013.

De Leeun, J. A., Bolhuis, E. J., Bosh, G. and Gerrits W. J. J. 2008.Effects of dietry fibre on behavior and safety in pigs. Poultry Nutrition Society 67: $334-342$.

Egbunike, G. N., Agiang, E. A., Owosibo, A. O., and Fatufe, A. A. 2009. Effect of protein on performance and haematology of broilers fed cassava peel based diet. Arch Zootech, 58: 655-662.

Elijah, I. O. 2015. A Decade (2002-2012) of presidential intervention on cassava in Nigeria; the successes and challenges .Asian Journal of Agricultural Extension, Economics and Sociology. 6(4): 185-193. AJ AEES.2015.076. ISSN:2320-7027

FAOSTAT 2015. Production: Crops. http://faostat3.fao.org/browse/Q/ QC/EAccessed May 6, 2015

F A O

20113. http://faostat.fao.org/site/339/defa ult.aspx Accessed January 5, 2013

FAO 2001. Strategic environmental assessment. An assessment of the impact of cassava production and processing on the environment and biodiversity. Proceedings of the validation forum on the global cassava development strategy, Volume 5. FAO, Rome, 26-28 April 2000.

Gardnea, K. H. and Blackwell J. 1974. Microbiological enzymes and bioconversion, in: Economic Microbiology vol. 5 (ed. A. H. Rose). Academic Press, London pp. 283-372.

Heuze, H., Tran, G., Bastianelli, D., Archimede, H., Lebas, F. S., and Reginer C. 2014.Cassava tubers, Feedipedia.org. A programme by Institute national de la recherché agronomique,, Centre de cooperation internationale en recherche, and Food and Agricultural Organization

INRA, CIRAD, AFZ and FAO. 2012. Cassava foliage, fresh. FeedipediaAnimal Feed Resources I n f or m a tion $\mathrm{Sys}$ te $\mathrm{m}$ http://www.feedipedia.org/node/1 1678. Accessed February 9, 2013.

Makinde, O. A. and Sonaiya, E. B. 2007. Determination of water blood and rumen fluid absorbencies of some fibrous feed stuff. Livestock Research for Rural Development, $9(10)$.

Mortajemi, Y. 2002. Impact of small scale fermentation technology on food safety in developing countries. International Journal of Food Microbiology.75 (3): 213-229.

Nwokoro, S. O., Adegunloye, H. D. and Ikhinmwin, A. F. 2005. Nutritional composition of garrisievates collected from some locations in Southern Nigeria. Pakistan Journal of Nutrition, 4(4): 257-261

Obi, I. U. 1990. Statistical methods of detecting differences between 
Physico-chemical composition of feed grade cassava peel meal fermented with different levels of baker's yeast

treatment means. Snap Press, Enugu, Nigeria.

Oboh, G. 2006. Nutrient enrichment of cassava peel using mixed culture of Saccharomyces cerevisae and Lactobacillus sp. Solid media fermentation techniques. Electronic Journal of Biotechnololgy, 9(1): 46-49.

Oboh, G., Akindahunsi, A. A. and Oshodi, A. A. 2002. Nutrient and Antinutrient content of Aspergillus niger fermented cassava products (flour and garri). Journal of food Composition Analysis 15(5):617622

Oboh, G. and Elusiyan, C. A. 2007. Changes in the nutrient and antinutrient content of micro-fungi fermented cassava flour produced from low and medium cyanide variety of cassava tubers. African Journal of Biotechnology, 6(18): $2150-2157$.

Oboh, G., and Akindahunsi, A. A. 2003. Chemical changes in cassava peels fermented with mixed culture of Aspergillus niger and two species of Lactobacillus integrated biosystem. Applied Tropoical Agriculture, 8: 63-68.

Ogbo, F. C. and Odo, M. O. 2011. Potiential of rice husk and cassava peels as carrier in biofertilizer production. Nigerian Journal of biotechnology. 23:1-4

Okoli, I. C., Okparaocha, C. O., Chinweze, E. C. and Udedibie, A. B. I. 2012. Physiochemical and hydrogen cyanide content of three processed cassava products used for feeding poultry in Nigeria. Asian Journal of Animal and Veterinary. Advances, 7:334-340.

Omede, A. A., Okoli, I. C. and Uchegbu, M. C. 2011. Studies of the physical characteristics of some feed ingredients in Nigeria 2: Energy source and novel feedstuffs. Online Journal of Animal Feed Research, 1(5): 198-204.

Osei, S. A., Asiamah, M. and Atuhene, C. C. 1990. Effects of fermented cassava peel meal on the performance of layers, Animal Feed Science and Technology, 29 (3-4): $295-301$.

Osman, M. A. 2011. Effect of traditional fermentation process on the nutrient content of pearl millet during preparation of Lohor. Journal of Saudi Society of Agricultural Science. 10:1-6

Pandy, A., Soccol, C. R., Nigam, P., Soccol, V. T., Vandenbeigh, L. P. S. and Mohan, R. 2000 . Biotechnology potential of agro industrial residue II: Cassava baggase. Bioresources Technology, 74(1): $81-87$.

Portella, F., Caston, I. J. and Lesson, S. 1988. Apparent feed particle size preference by broilers, Canadian Journal of Animal Science, 68: 923 $-930$.

R-Core Team 2012. R: A language and environment for statistical computing. R. Foundation for statistical computing Vienna Austria. ISBN 3-900051-07 - 0. URL-http://www.R.project.org.

Salami, R. I. and Odunsi, A. A. 2003. Evaluation of processed cassava peel meals as a substitute for maize in the diets of layers. International Journal of Poultry Science, 2(2): $112-116$

Smith, C. N. M. and Annison, G. 1996. Non Starch, plant polysaccharide in broiler nutrition towards a physiological valid approach in their determination, World Poultry 
Science,52: 203-223.

Snedecor, G. W. and Cochran, I. N. G. 1975. Statistical method $6^{\text {th }}$ edition. Iowa State University Press, Ames. Pp. 258-296.

Sundu, B., Kumar, A. and Dingle, J. 2005. Growth pattern of broilers fed a physically enzymatically treated copra meal diet. In: Proceedings of the $17^{\text {th }}$ Australian Poultry science symposium, Sydney, new South Wales, Australia, 7-9 February 2005. 291294

Tewe, O. O. 2004. The global cassava development strategy: cassava for livestock feed in Sub-Saharan Africa. IFAD and FAO

Tewe, O. O. 1992. Detoxification of cassava products and effects of residual toxins on consuming animals. In: Machin, D., Nyvold, S., 1992. Roots, tubers, plantain and banana in animal feeding. Proceedings of the FAO Expert Consultation held in CIAT, Cali, Colombia@!-25 January 1991; FAO Animal Production and Health Paper 95
Ubulua, A. O. 2007. Cassava wastes: Treatment value addition alternative, African Journal of Biotechnology, 6(1): 2065-2073.

Ukachukwu S. N. 2005. Studies on the nutritive value of composite cassava pellet for poultry: chemical composition in metabolisable energy. Livestock Research for Rural Development 17 (11): 2005.

Received: $12^{\text {th }}$ May, 2018

Accepted: $31^{\text {st }}$ August, 2018 